\title{
Antioxidant and tyrosinase inhibitory activities of immature fruits of Malus pumila cv. Fuji
}

\author{
O Jun Kwon* \\ Gyeongbuk Institute For Regional Program Evaluation, Gyeongsan 38542, Korea
}

\section{미성숙 사과의 항산화 및 tyrosinase 저해 활성 평가}

\author{
권오준* \\ (재)경북지역사업평가단 평가팀
}

\begin{abstract}
In this study, the antioxidant and tyrosinase inhibitory activities of aqueous ethanolic extract from the immature fruits of Malus pumila cv. Fuji were evaluated. The antioxidant capacities of the extract was investigated employing radical scavenging assays using DPPH and $\mathrm{ABTS}^{+}$radicals. The skin-whitening effect of M. pumila cv. Fuji extract was tested using mushroom tyrosinase assay. In addition, the total phenolic content was measured by a spectrophotometric analysis. All tested samples showed a dose-dependent radical scavenging and tyrosinase inhibitory activities. Among the tested samples, the ethyl acetate (EtOAc)-soluble portion from the immature fruits of $M$. pumila cv. Fuji was showed the significant DPPH and $\mathrm{ABTS}^{+}$radicals scavenging activities. Also, the tyrosinase inhibitory activity of the ethyl acetate (EtOAc)-soluble portion from immature apples was higher than other solvent-soluble portion. These results suggest that unripe fruits of $M$. pumila cv. Fuji could be considered as a new valuable source of natural antioxidant and skin-whitening agents. Systematic investigation of immature fruits of Malus pumila cv. Fuji will be performed for the further development of its biological properties.
\end{abstract}

Key words : Malus pumila cv. Fuji, unripe fruit, DPPH, $\mathrm{ABTS}^{+}$, tyrosinase, phenolics

\section{서 론}

인간은 현대 사회 속의 다양한 요인들에 의해 인체에서 산화촉진물질(prooxidant)과 산화억제물질(antioxidant)의 불균형에 의해 산화 촉진이 일어나면 산화적 스트레스가 유발된다(1). 최근 이러한 요인에 의해 유발되는 산화적 스트레스와 관련된 각종 퇴행성 질환 및 생활 습관성 질병 이 사회적 문제로 대두되고 있으며 그 원인의 하나로서 활성산소가 잘 알려져 있다(2). 활성산소종(reactive oxygen species, ROS)은 인간의 대사과정 중에 끊임없이 발생되며 불안정하고 반응성이 높아 여러 생체물질과 쉽게 반응하

*Corresponding author. E-mail : ojkwon@irpe.or.kr Phone : 82-53-818-9504, Fax : 82-53-818-9504

Received 27 June 2016; Revised 6 July 2016; Accepted 11 July 2016

Copyright (c) The Korean Society of Food Preservation. All rights reserved.
고, 체내 고분자들을 공격하여 세포와 조직에 비가역적인 손상을 일으키거나 돌연변이, 세포독성 및 발암 등을 초래 하게 되며(3), superoxide, nitric oxide, nitrogen dioxide, hydroxyl, peroxynitrite 등이 보고되어 있다(4). 생체 내에서 활성산소종이나 free radical이 DNA를 공격하거나, 지질을 산화시키기 전에 그들을 중화시켜 노화방지, 성인병 예방 등의 기능을 하는 것이 항산화제이며(5,6), 현재 널리 사용 되고 있는 항산화제로서는 butylated hydroxy anisol(BHA) 및 butylated hydroxy toluene(BHT) 등의 합성 항산화제이 며, 이들을 $50 \mathrm{mg} / \mathrm{kg} / \mathrm{day}$ 이상의 고용량으로 장기간 복용 시 지질대사의 불균형과 암을 유발시킬 수 있으므로 사용이 제한되고 있다(7). 이러한 합성 항산화제를 대체할 수 있는 보다 우수하고 안전한 천연 소재의 개발이 요구되고 있으 며, 최근에는 각종 천연소재 등에서 안전성이 확보된 우수 한 항산화효능의 천연 항산화제를 개발하기 위한 많은 연구 에 의해 블루베리, 셀러리, 감귤 및 포도 등에도 강력한 항산화 성분이 함유되어 있음이 알려져 있다(8). 
Melanin은 피부의 색조를 결정하는 주요한 인자로서 표 피 기저층의 melanocyte라고 불리는 색소세포내의 melanosome 에서 생합성된다. 멜라닌을 합성하는 출발물질은 아미노산 의 일종인 tyrosine이며, 멜라닌세포내에서 tyrosinase에 의 해 DOPA, DOPA quinone으로 산화되며 DOPA chrome, 5,6-dihydroxyindole, indole-5,6-quinone이 되고, 그 후 indole-5,6-quinone으로 중합에 의해 melanin을 생성하는 것 으로 알려져 있다 $(9,10)$. Tyrosinase는 피부에서 멜라닌 생 성과 관련하여 매우 중요한 역할을 하고 있으며, melanosome내에서 tyrosine을 산화시켜 DOPA를 생성하는 tyrosinase hydroxylase로, DOPA를 산화시켜 DOPA quinone 을 만드는 DOPA oxidase로서 작용하여 멜라닌중합체를 합성하는 key enzyme으로 작용한다(11). 따라서 tyrosinase 의 활성억제는 피부내에서의 멜라닌 중합체 생합성을 효과 적으로 저해할 수 있으므로, 피부 미백제 개발에 있어서 tyrosinase 활성억제시험은 유용한 방법으로 광범위하게 활 용하고 있다. 현재까지 천연물 유래의 tyrosinase 활성억제 물질로서는 누룩곰팡이의 2차대사산물인 kojic acid와 우바 우르시 잎으로부터 분리된 arbutin, 상백피의 oxyresveratrol 등이 있으며, 그 외에도 stilbene계 화합물 및 flavonoid계 화합물 등이 있다 $(12,13)$. 이들 중 kojic acid 및 arbutin은 미백 기능성 물질로서 상업화되어 있으나 독성 및 부작용으 로 인하여 보다 안전한 천연소재로의 대체가 요구되고 있 다.

사과(Malus pumila cv. Fuji)는 장미과(Rosaceae)에 속하 는 작은 낙엽성의 나무로서 유럽, 아시아 및 북아메리카의 북반구에 재배 된다. 사과에는 건강증진 효능을 나타낼 수 있는 식이섬유, 당류, 비타민류 및 페놀성 화합물이 다량 함유되어 있다. 최근의 연구에 따르면 사과에는 다양한 종 류의 polyphenol 화합물이 존재하며 항비만, 항염증, 항알러 지, 주름개선 등의 활성을 나타내는 것이 알려져 있다 (14-19). 또한 레드 와인 및 사과 polyphenol의 주성분인 proanthocyanin은 심혈관계질환에 효과적인 것으로 연구자 들의 주목을 받고 있다(20).

본 연구에서는 약용식물로부터 항산화 및 tyrosinase 저 해활성을 나타내는 천연소재를 탐색하고자 국내의 자생식 물을 대상으로 효능을 평가하였으며, 그중에서 우수한 저 해능을 나타낸 미성숙 사과의 $70 \% \mathrm{EtOH}$ 추출물 및 각 분획 물에 대하여 강한 라디칼 소거능 및 tyrosinase 저해능을 확인하였기에 그 결과를 보고하고자 한다.

\section{재료 및 방법}

\section{실험재료}

본 실험에 시료로 사용한 미성숙 사과(Malus pumila cv. Fuji)는 2014년 5월에 경북 영천시에서 채취한 신선 미성숙
사과를 마쇄한 다음 사용하였다.

\section{추출물의 제조 및 분획}

신선한 미성숙 사과 $2.0 \mathrm{~kg}$ 을 잘게 자른 후 $70 \%$ ethyl alcohol $(\mathrm{EtOH}) 7 \mathrm{~L}$ 로 3일간 실온에서 3회 반복 추출한 후 얻어진 추출액을 여과한 후, 감압 농축(Rotary vacuum evaporator N-N series, Eyela, Tokyo, Japan)하여 얻어진 추 출물 $(112.9 \mathrm{~g})$ 에 대해 항산화 효능의 평가로 이용된 $\mathrm{DPPH}$ 및 $\mathrm{ABTS}^{+}$라디칼에 대해서 각각의 시험농도에서 라디칼소 거활성을 평가하였으며, tyrosinase 저해활성도 이전의 실 험방법에 $(21,22)$ 준하여 수행하였다. 활성부분에 함유되어 있는 활성물질의 형태를 추정하기 위해 Fig. 1과 같이 농축 결과물을 $10 \% \mathrm{MeOH}$ 로 현탁하여 저극성 용매인 $n$-Haxane 으로 먼저 추출한 후 수층을 다시 ethyl acetate(EtOAc), $n$-butyl alcohol $(n-\mathrm{BuOH})$ 을 이용하여 각각 순차적으로 3 회 분획하여 추출하였다. 각 용매추출 분획을 감압 농축하여 건조 시킨 후 $n$-Haxane 가용분획 $(1.1 \mathrm{~g})$, EtOAc 가용분획 $(18.8 \mathrm{~g}), n-\mathrm{BuOH}$ 가용분획(17.6 g), $\mathrm{H}_{2} \mathrm{O}$ 가용분획(73.6 g)을 각각 얻었으며 각 분획물을 대상으로 라디칼 소거능 및 tyrosinase 저해 활성을 평가하였다.

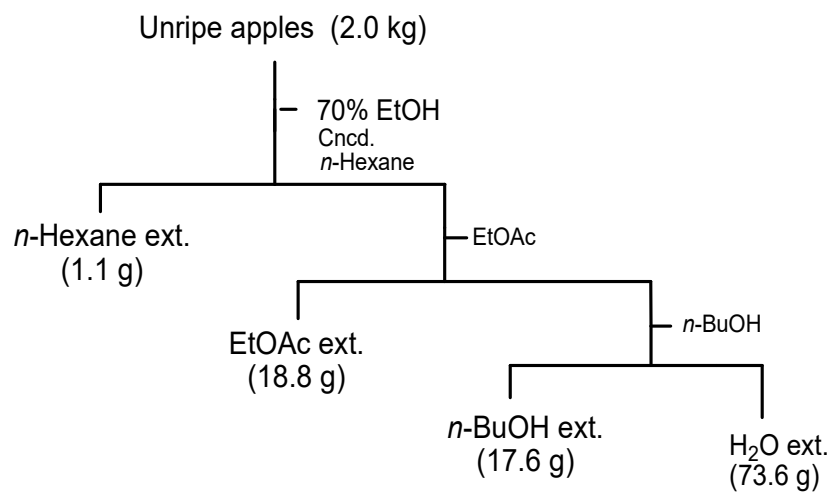

Fig. 1. Extraction and isolation of $70 \%$ ethanolic extract from the immature fruits of Malus pumila cv. Fuji.

\section{$\mathrm{DPPH}$ 라디칼소거능 측정}

미성숙 사과 $70 \%$ ethanol 추출물의 전자공여능은 Blois 방법(19)에 따라 측정하였다. 각 시료용액에 $120 \mu \mathrm{L}$ 에 0.45 $\mathrm{mM}$ 의 희석한 1,1-diphenyl-2-picrylhydrazyl(DPPH) 용액 60 $\mu \mathrm{L}$ 을 넣고 교반한 후 15 분간 방치한 다음 $517 \mathrm{~nm}$ 에서 흡광 도를 측정하였다. 이때 대조물질로는 (+)-catechin(SigmaAldrich Co., St. Louis, MO, USA)를 사용했으며 전자공여능 은 시료용액의 첨가군과 무첨가군의 흡광도 차이를 백분율 로 나타내었다.

\section{$\mathrm{ABTS}^{+}$라디칼 소거능 측정}

미성숙 사과 $70 \%$ methanol 추출물의 2,2'-azinobis-3ethylbenzothiazoline-6-sulfonic acid(ABTS) radical 소거능 
을 $\mathrm{Re}$ 의 방법(20)을 변형하여 다음과 같이 측정하였다. 7 $\mathrm{mM} \mathrm{ABTS(in} \mathrm{water)와} 2.4 \mathrm{mM} \mathrm{K}_{2} \mathrm{O}_{8} \mathrm{~S}_{2}$ 동량을 혼합 후 실온, 암소에서 12시간 방치하여 라디칼의 생성을 유도한 후 $\mathrm{ABTS}^{+}$라디칼 용액을 희석하여 $734 \mathrm{~nm}$ 에서 흡광도 값이 0.6 정도가 되도록 희석하여 사용하였다. 희석한 ABTS+ 라디칼 용액 $100 \mu \mathrm{L}$ 와 생약 추출액 $100 \mu \mathrm{L}$ 을 혼합하여 실온에서 7분간 반응시킨 후 $734 \mathrm{~nm}$ 에서 흡광도를 측정하 였다. 이때 대조물질로는 (+)-catechin를 사용하였으며 결과 는 시료를 처리하지 않은 군에 대한 \%로 표시하였다.

\section{Tyrosinase 저해활성 측정}

Tyrosinase의 작용 결과 생성되는 DOPA chrome을 비색 법에 의해 측정하는 Yagi 등의 방법(23)에 따라 실시하였다. 반응구는 $0.175 \mathrm{M}$ sodium phosphate buffer(pH 6.8$) 0.5 \mathrm{~mL}$ 에 $10 \mathrm{mM} \mathrm{L-DOPA} 0.2 \mathrm{~mL}$ 및 시료용액 $0.1 \mathrm{~mL}$ 의 혼합액에 mushroom tyrosinase $(110 \mathrm{U} / \mathrm{mL}$, Sigma-Aldrich Co., St. Louis, $\mathrm{MO}, \mathrm{USA}) 0.2 \mathrm{~mL}$ 첨가하여 $37^{\circ} \mathrm{C}$ 에서 2 분간 반응시 켜 반응액 중에 생성된 DOPA chrome을 $475 \mathrm{~nm}$ 에서 흡광도 를 측정하였다. Tyrosinase 저해활성은 시료 용액의 첨가군 과 무첨가군의 흡광도 감소율로 나타내었다.

\section{총페놀성 화합물 함량 평가}

총 페놀성 화합물의 함량은 Folin-Denis 방법(24)에 따라 측정하였으며, 추출물 혹은 분획물을 $1.0 \mathrm{mg} / \mathrm{mL}$ 농도로 조제한 후, $75 \mathrm{~mL}$ 의 증류수가 함유된 $100 \mathrm{~mL}$ 의 시험관에 $1 \mathrm{~mL}$ 을 넣고 잘 혼합하여 Folin-Denis 시액 $5 \mathrm{~mL}$ 와 탄산나 트륨 포화용액 $15 \mathrm{~mL}$ 를 차례로 넣은 다음 이것을 잘 혼합하 여 실온에서 60 분 방치한 후, UV/VIS 분광광도계로 640 $\mathrm{nm}$ 에서 흡광도를 측정하였으며, 표준물질은 tannic acid(Sigma-Aldrich Co., St. Louis, MO, USA)를 이용하여 표준곡선을 작성하여 양을 환산하였다.

\section{결과 및 고찰}

\section{$\mathrm{DPPH}$ 라디칼 소거활성}

생체 내에 존재하는 라디칼은 아니지만 $\mathrm{DPPH}$ 는 그 자체 가 홀수전자를 갖고 있어 $517 \mathrm{~nm}$ 에서 강한 흡광도를 나타 낸다. 따라서 항산화능이 있는 물질과 반응하게 되면 안정 한 형태로 돌아가면서 흡광도 값이 감소한다(25). Fig. 2에 서 나타낸 것처럼 성숙 및 미성숙 사과 $70 \% \mathrm{EtOH}$ 추출물 및 각 유기용매 분획에 대해서 DPPH 라디칼 소거활성을 평가한 결과, 성숙 사과의 $70 \% \mathrm{EtOH}$ 추출물의 $\mathrm{IC}_{50}$ 값은 $304.6 \pm 8.1 \mu \mathrm{g} / \mathrm{mL}$, 미성숙 사과의 $70 \% \mathrm{EtOH}$ 추출물의 $\mathrm{IC}_{50}$ 값은 $115.4 \pm 6.4 \mathrm{\mu g} / \mathrm{mL}$ 로 미성숙 사과 $70 \% \mathrm{EtOH}$ 추출물에 서 더욱 우수한 활성을 나타내었다. 또한 미성숙 사과의 $\mathrm{EtOAc}$ 가용부의 $\mathrm{IC}_{50}$ 값은 $51.2 \pm 1.9 \mu \mathrm{g} / \mathrm{mL}$ 으로 상대적으로
가장 우수한 활성을 나타내었으며, positive control인 (+)-catechin의 활성에 상당하는 효능을 확인하였다. 다음으 로 $n-\mathrm{BuOH}$ 가용부의 $\mathrm{IC}_{50}$ 값은 $78.9 \pm 3.1 \mathrm{\mu g} / \mathrm{mL}, \mathrm{H}_{2} \mathrm{O}$ 가용부 의 $\mathrm{IC}_{50}$ 값은 $211.7 \pm 10.1 \mu \mathrm{g} / \mathrm{mL}, n-H e x a n e$ 의 $\mathrm{IC}_{50}$ 값은 $>500$ $\mu \mathrm{g} / \mathrm{mL}$ 의 순으로 라디칼 소거활성을 나타냄을 확인하였다. $\mathrm{DPPH}$ 라디칼 소거능과 총 페놀성 화합물의 함량사이에는 밀접한 상관관계가 있다는 보고(26)에 근거하여 미성숙사 과의 항산화 활성과 페놀성 화합물의 연관성을 평가한 결 과, Fig. 2 및 Table 1에서 나타낸 것처럼, DPPH 라디칼 소거능은 페놀성 화합물의 함량이 상대적으로 높은 $\mathrm{EtOAc}$ 및 $n-\mathrm{BuOH}$ 가용부에서 가장 우수한 것을 확인할 수 있다.

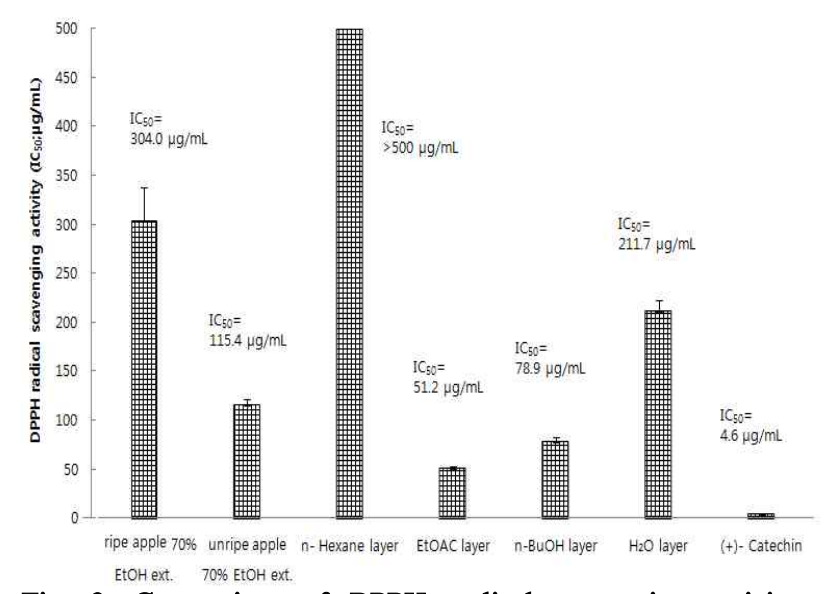

Fig. 2. Comparison of DPPH radical scavenging activity of immature apple extract and solvent-soluble portion.

Data represent the mean \pm SD three replication and $(+)$-catechin was used as a positive control.

Table 1. Total phenolic contents of the $70 \%$ ethanolic extract and organic solvent fractions of immature apple

\begin{tabular}{ccc}
\hline Samples & $\begin{array}{c}\text { Extraction Yield } \\
(\mathrm{g} / 100 \mathrm{~g})\end{array}$ & $\begin{array}{c}\text { Phenolic Contents } \\
(\mathrm{mg} / \mathrm{g})\end{array}$ \\
\hline $70 \%$ EtOH ext. of ripe apple & 4.8 & $2.0 \pm 0.2^{1)}$ \\
$70 \%$ EtOH ext. of immature apple & 5.6 & $4.7 \pm 0.2$ \\
$n$-Hexane layer & 0.01 & $1.6 \pm 0.2$ \\
EtOAc layer & 0.9 & $6.4 \pm 0.3$ \\
$n-\mathrm{BuOH}$ layer & 0.9 & $4.1 \pm 0.5$ \\
$\mathrm{H}_{2} \mathrm{O}$ layer & 3.7 & $2.6 \pm 0.2$ \\
\hline
\end{tabular}

${ }^{1)}$ Each value is expressed as the mean $\pm \mathrm{SD}$ of triplicate determinations

\section{$\mathrm{ABTS}^{+}$라디칼 소거능 측정}

$\mathrm{ABTS}^{+}$라디칼 소거활성을 측정한 결과 Fig. 3에서 보는 것처럼 성숙 사과의 $70 \% \mathrm{EtOH}$ 추출물의 $\mathrm{IC}_{50}$ 값은 $341.1 \pm 14.8 \mathrm{\mu g} / \mathrm{mL}$, 미성숙 사과의 $70 \% \mathrm{EtOH}$ 추출물의 $\mathrm{IC}_{50}$ 값은 $45.4 \pm 9.3 \mu \mathrm{g} / \mathrm{mL}$ 로 미성숙 사과 $70 \% \mathrm{EtOH}$ 추출물에서 더욱 우수한 $\mathrm{ABTS}^{+}$라디칼 소거활성을 나타내었다. 또한 미성숙 사과의 $\mathrm{EtOAc}$ 분획층의 $\mathrm{IC}_{50}$ 값은 $28.3 \pm 1.5 \mu \mathrm{g} / \mathrm{mL}$ 으 
로 상대적으로 가장 우수한 활성을 나타내었으며, positive control인 (+)-catechin의 $\mathrm{IC}_{50}$ 값인 $1.3 \pm 0.2 \mathrm{\mu g} / \mathrm{mL}$ 의 활성보 다는 약한 활성임을 확인하였다. 한편, $n-\mathrm{BuOH}$ 가용부의 $\mathrm{IC}_{50}$ 값은 $49.8 \pm 2.1 \mu \mathrm{g} / \mathrm{mL}, \mathrm{H}_{2} \mathrm{O}$ 가용부의 $\mathrm{IC}_{50}$ 값은 $143.8 \pm 3.3$ $\mu \mathrm{g} / \mathrm{mL}, n$-Hexane의 $\mathrm{IC}_{50}$ 값은 $115.4 \pm 11.6 \mu \mathrm{g} / \mathrm{mL}$ 의 순으로 라디칼 소거활성을 나타냄을 확인하였다. Table 1에서 나타 낸 것처럼 총 페놀성 함량 상대적으로 높게 나타난 EtOAc, $n-\mathrm{BuOH}$ 층에 $\mathrm{ABTS}^{+}$라디칼 소거 활성물질의 존재가 시사 되었으며, 특히 $\mathrm{EtOAc}$ 층에 대해서 이들 라디칼소거활성을 가진 항산화물질의 동정이 필요하다고 사료된다.

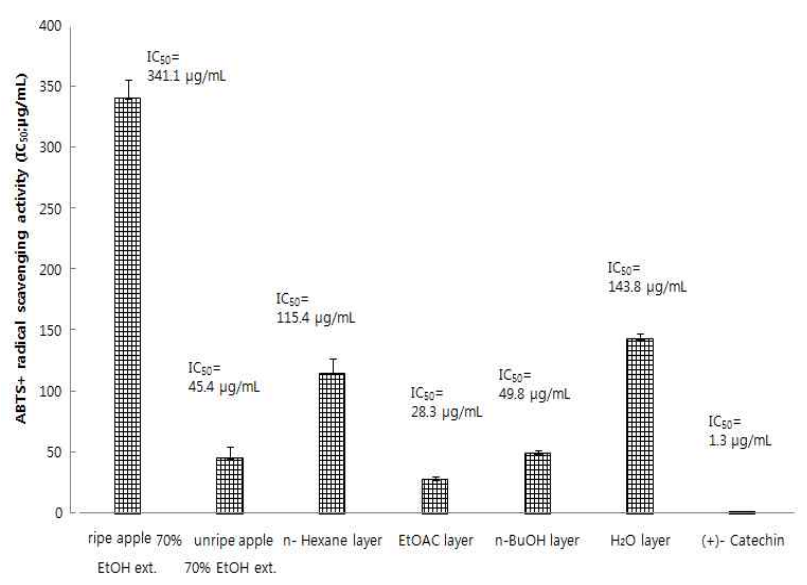

Fig. 3. Comparison of $\mathrm{ABTS}^{+}$radical scavenging activity of immature apple extract and solvent-soluble portion.

Data represent the mean $\pm \mathrm{SD}$ three replication and $(+)$-catechin was used as a positive control.

\section{Tyrosinase 저해활성}

전통 천연 식물로부터 항산화 및 멜라닌생성 억제 선도 물질개발을 목표로 하여 미성숙 사과의 $70 \% \mathrm{EtOH}$ 추출물 을 극성에 따라 $n$-hexane, EtOAc, $n-\mathrm{BuOH}$ 로 순차 분획하여 얻어진 각 분획에 대하여 mushroom tyrosinase를 이용한 실험을 통해 활성을 평가하였다. 그 결과 Fig. 4에서 나타낸 것처럼 성숙 및 미성숙 사과 $70 \% \mathrm{EtOH}$ 추출물 및 각 유기용 매 분획에 대해서 tyrosinase 저해활성을 평가한 결과, 성숙 사과의 $70 \% \mathrm{EtOH}$ 추출물의 $\mathrm{IC}_{50}$ 값은 $>200 \mu \mathrm{g} / \mathrm{mL}$ 으로 약한 활성을 나타내었으며, 미성숙 사과의 $70 \% \mathrm{EtOH}$ 추출물의 $\mathrm{IC}_{50}$ 값은 $173.0 \pm 3.2 \mathrm{\mu g} / \mathrm{mL}$ 으로 성숙 사과의 함수 $\mathrm{EtOH}$ 추 출물보다 우수한 활성을 나타내었다. 상대적으로 우수한 효소 저해활성을 나타낸 미성숙 사과의 $\mathrm{EtOAc}$ 분획층의 $\mathrm{IC}_{50}$ 값은 $101.2 \pm 1.7 \mu \mathrm{g} / \mathrm{mL}$ 이였으며, positive control인 kojic $\mathrm{acid}$ 의 $\mathrm{IC}_{50}$ 값인 $57.2 \pm 2.1 \mathrm{\mu g} / \mathrm{mL}$ 의 활성보다는 약한 활성임 을 확인하였다. 한편, $n-\mathrm{BuOH}, \mathrm{H}_{2} \mathrm{O}$ 및 $n-\mathrm{Hexane}$ 가용부의 $\mathrm{IC}_{50}$ 값은 $>200 \mu \mathrm{g} / \mathrm{mL}$ 의 상대적으로 약한 tyrosinase 저해활 성을 나타냄을 확인하였다. 최근 천연소재로부터 tyrosinase 저해활성이 우수한 멜라닌 생성 억제 소재 발굴을 위하여 진행된 연구에 의하면 아보카도(Persea americana)의 catechin 유도체인 proanthocyanidin이 우수한 효능을 나타 내었으며(27), 캐럽나무(Ceratonia siliqua) 추출물의 1,2,3,6tetra-O-galloyl-B-D-glucoside의 $\mathrm{IC}_{50}$ 값은 $83.3 \mathrm{\mu g} / \mathrm{mL}$ 을 나 타냄을 확인하였다(28). 이상의 결과 및 최근의 tyrosinase 저해 활성과 관련된 화합물 중 페놀성 화합물이 멜라닌 생성 억제 활성을 나타내는 물질이 다수 보고되어져 있으 며, 미성숙 사과의 멜라닌 생성 억제 활성성분으로 추정되 는 페놀성 화합물의 분리, 동정 및 활성기작 평가를 통하여 미성숙 사과 추출물의 우수한 미백 소재로서의 추가적인 연구가 필요하다고 사료된다.

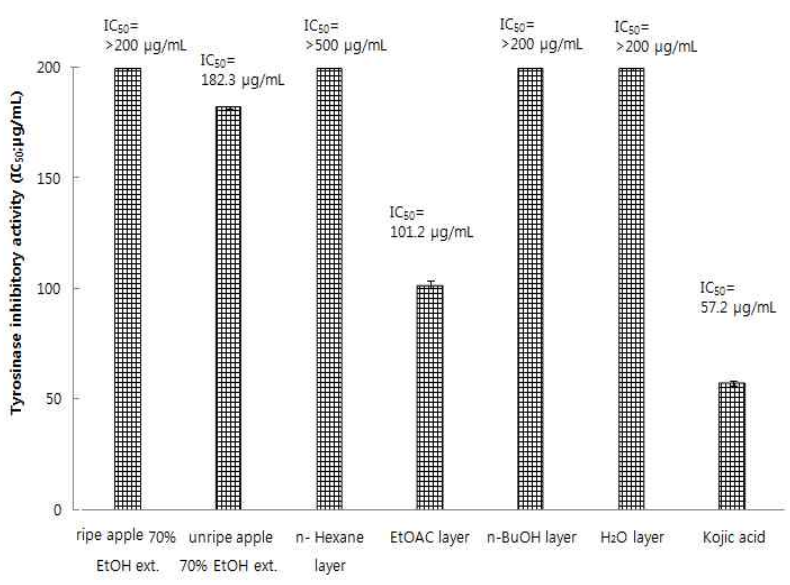

Fig. 4. Tyrosinase inhibitory activity of immature apple extract and solvent-soluble portion.

Data represent the mean \pm SD three replication and (+)-catechin was used as a positive control.

\section{총페놀 화합물 함량}

성숙 및 미성숙 사과 $70 \% \mathrm{EtOH}$ 추출물 및 각 유기용매 분획에 대해서 시료 중의 총페놀성 화합물의 함량을 Table 1 에 나타내었으며, 성숙 사과의 $70 \% \mathrm{EtOH}$ 추출물보다 미 성숙 사과의 $70 \% \mathrm{EtOH}$ 추출물에서 $1 \mathrm{~g}$ 당 $4.7 \pm 0.2 \mathrm{mg}$ 으로 페놀성 화합물의 함량이 높게 나타났다. 또한 미성숙 사과 의 $70 \% \mathrm{EtOH}$ 추출물의 $\mathrm{EtOAc}$ 분획물이 $1 \mathrm{~g}$ 당 $6.4 \pm 0.3$ $\mathrm{mg}$ 의 페놀성 화합물을 함유하는 것으로 나타났으며, $n-\mathrm{BuOH}$ 분획물이 $1 \mathrm{~g}$ 당 $4.1 \pm 0.5 \mathrm{mg}, \mathrm{H}_{2} \mathrm{O}$ 층에서는 $1 \mathrm{~g}$ 당 $2.6 \pm 0.2 \mathrm{mg}$ 의 페놀성 화합물의 함량이 확인되었다. 또한 $n$-hexane 분획물이 $1 \mathrm{~g}$ 당 $1.6 \pm 0.2 \mathrm{mg}$ 의 상대적으로 낮은 페놀성 화합물의 함류량을 나타내는 것으로 분석되었다. 최근 미성숙 사과 및 성숙사과의 페놀성 화합물의 함량에 대한 연구를 통하여 미성숙사과에서 chlorogenic acid의 함 량이 상대적으로 높은 것을 확인하였으며(29), DPPH 라디 칼 소거활성이 강한 chlorogenic $\operatorname{acid}(30)$ 에 의하여 미성숙 사과의 라디칼 소거 활성이 상대적으로 우수함을 시사하 였다. 


\section{요 약}

미성숙 사과를 $70 \%$ ethanol 추출물에 대해 $n$-hexane, $\mathrm{EtOAc}$ 및 $n \mathrm{BuOH}$ 로 순차 용매 분획하였고, 얻어진 결과물 에 대하여 $\mathrm{DPPH}$ 및 $\mathrm{ABTS}^{+}$radical 소거능 및 tyrosinase 저해활성을 평가하였다. DPPH 라디칼 소거능은 페놀성 화합물의 함량이 상대적으로 높은 $\mathrm{EtOAc}$ 가용부의 $\mathrm{IC}_{50}$ 값 은 $51.2 \pm 1.9 \mu \mathrm{g} / \mathrm{mL}$ 으로 상대적으로 가장 우수한 활성을 확인 하였으며, 미성숙 사과 알콜 추출물에 존재하는 페놀 성 화합물이 라디칼 소거능과의 연관성을 시사하였다. 또 한 $\mathrm{ABTS}^{+}$라디칼 소거능은 $\mathrm{EtOAc}$ 층의 $\mathrm{IC}_{50}$ 값은 $28.3 \pm 1.5$ $\mu \mathrm{g} / \mathrm{mL}$ 의 소거 활성이 확인 되었고, 강한 활성물질의 존재가 시사되었다. 또한, tyrosinase 저해활성을 측정한 결과, 상대 적으로 우수한 $\mathrm{DPPH}$ 및 $\mathrm{ABTS}^{+}$라디칼 소거능을 나타낸 $\mathrm{EtOAc}$ 층의 $\mathrm{IC}_{50}$ 은 $101.2 \pm 1.7 \mathrm{mg} / \mathrm{mL}$ 의 저해 활성을 나타내 었으며 이는 대조군인 kojic acid의 $\mathrm{IC}_{50}$ 값인 $57.2 \pm 2.1 \mathrm{\mu g} / \mathrm{mL}$ 에 비해 약하나 단일물질로 정제할 경우 더욱 강한 효능의 화합물이 존재할 가능성이 있음을 시사하였다. 향후 이들 활성물질 동정을 통한 활성 기작에 대한 연구가 필요하며 본 연구결과는 보다 우수한 라디칼 소거능 및 tyrosinase 저해능을 가지는 새로운 선도화합물 발굴을 위한 기초자료 로 활용가능하리라 사료된다.

\section{References}

1. Videla LA, Fermandez V (1988) Biochemical aspects of cellular oxidative stress. Arch Biol Med Exp, 21, 85-92

2. Halliwell B, Aruoma OJ (1991) DNA damage by oxygen-derived species. FEBS Lett, 281, 9-19

3. Jennings PE, Barnett AH (1988) New approaches to the pathogenesis and treatment of diabetic microangiopathy. Diabetic Med, 5, 111-117

4. Shim JS, Kim SD, Kim TS, Kim KN (2005) Biological activities of flavonoid glycosides isolated from Angelica keiskei. Korean J Food Sci Technol 37, 78-83

5. Farag RS, Badel AZMA, Hewedi FM, EL-baroty GSA (1989) Antioxidant activity of some spice essential oils on linoleic acid oxidation in aqueous media. J Am Oil Chem Soc, 66 792-799

6. Frei B (1994) National antioxidants in human health and disease. Academic Press, San Diego, CA, USA, p 44-55

7. Branen AL (1975) Toxicology and biochemistry of butylated hydroxyanisole and bytylated hydroxytoluene. J AM Oil Chem Soc, 52, 59-63

8. Masaki H, Sakaki S, Atsumi T, Sakurai H (1995) Active-oxygen scavenging activity of plant extracts. Biol
Pharm Bull, 18, 162-166

9. Prota G (1980) Recent advances in the chemistry of melanogenesis in mammals. J Invest Dermatol, 75, 122-127

10. Pavel S, Muskiet FA (1983) Eumelanin (precursor) metabolites as markers for pigmented malignant melanoma, a preliminary report. Cancer Detect Prev, 6, 311-316

11. Hearing VJ, Jimenez M (1987) Mammalian tyrosinase the critical regulatory control point in melanocyte pigmentation. Int J Biochem, 19, 1141-1147

12. Maeda K, Naitou T, Umishio K, Fukuhara T, Motoyama A (2007) A novel melanin inhibitor: hydroperoxy traxastane-type triterpene from flowers of Arnica montana. Biol Pharm Bull, 30, 873-879

13. Badria FA, elGayyar MA (2001) A new type of tyrosinase inhibitors from natural products as potential treatments for hyperpigmentation. Boll Chim Farm, 140, 267-271

14. Akiyama H, Sakushima J, Taniuchi S, Kanda T, Yanagida A, Kojima T, Teshima R, Kobayashi Y, Goda Y, Toyoda M (2000) Antiallergic effect of apple polyphenols on the allergic model mouse. Biol Pharm Bull, 23, 1370-1373

15. Tokura $T$, Nakano N, Ito $T$, Matsuda $H$, NagasakoAkazome Y, Kanda T, Ikeda M, Okumura K, Ogawa H, Nishiyama C (2005) Inhibitory effect of polyphenolenriched apple extracts on mast cell degranulation in vitro targeting the binding between IgE and FcepsilonRI. Biosci Biotechnol Biochem, 69, 1974-1977

16. Sugiyama H, Akazome Y, Shoji T, Yamaguchi A, Yasue M, Kanda T, Ohtake Y (2007) Oligomeric procyanidins in apple polyphenol are main active components for inhibition of pancreatic lipase and triglyceride absorption. J Agric Food Chem, 55, 4604-4609

17. Yoshioka Y, Akiyama H, Nakano M, Shoji T, Kanda T, Ohtake Y, Takita T, Matsuda R, Maitani T (2008) Orally administered apple procyanidins protect against experimental inflammatory bowel disease in mice. Int Immunopharmacol, 8, 1802-1807

18. Corder R, Mullen W, Khan NQ, Marks SC, Wood EG, Carrier MJ, Crozier A (2006) Oenology: Red wine procyanidins and vascular health. Nature, 444, 566

19. Blois MS (1958) Antioxidant activity determination by the use of a stable free radical. Nature, 181, 1199-1200

20. Re R, Pellegrini N, Proteggente A, Pannala A, Yang M, Rice-Evans C (1999) Antioxidnt activity applying and improved ABTS radical cation decolorization assay. Free Radic Biol Med, 26, 1231-1237 
21. Kwon OJ, Lee HY, Kim TH, Kim SG (2014) Antioxidant and pancreatic lipase inhibitory activities of Anemarrhena asphodeloides. Korean J Food Preserv, 21, 421-426

22. Kwon OJ, Bae JS, Lee HY, Hwang JY, Lee EW, Ito H, Kim TH (2013) Pancreatic lipase inhibitory gallotannins from Galla Rhois with inhibitory effects on adipocyte differentiation in 3T3-L1 cells. Molecules, 18, 10629-10638

23. Yagi A, Kanbara T, Morinobu N (1987) Inhibition of mushroom-tyrosinase by aloe extract. Planta Med, 53, 515-517

24. Gao X, Bjor, L, Trajkovski V, Uggla M (2000) Evaluation of antioxidant activities of rosehip ethanol extracts in different test system. J Sci Food Agric, 80, 2021-2027

25. Torel J, Cillard J, Cillard P (1986) Antioxidant activity of flavonoids and reactivity with peroxy radical. Phytochemistry, 25, 383-385

26. Wang SY, Chang HN, Lin KT, Lo CP, Yang NS, Shyur LF (2003) Antioxidant properties and phytochemical characteristics of extracts from Lactuca indica. J Agric Food Chem, 51, 1506-1512

27. Chai WM, Wei MK, Deng RG, Zou ZR, Peng YY (2015) Avocado proanthocyanidins as a source of tyrosinase inhibitors: structure characterization, inhibitory activity, and mechanism. J Agric Food Chem, 63, 7381-7387

28. Lall N, Kishore N, Momtaz S, Hussein A, Naidoo S, Nqephe M, Crampton B (2015) Extract from Ceratonia siliqua exhibits depigmentation properties. Phytother Res, 29, 1729-1736

29. Park EK, Ahn SR, Kim DH, Lee EW, Kwon HJ, Kim BW, Kim TH (2014) Effects of unripe apple polyphenols on the expression of matrix metalloproteinase- 1 and type-1 procollagen in ultraviolet irradiated human skin fibroblasts. J Korean Soc Appl Biol Chem, 57, 449-455

30. Olszewska MA, Michel P (2012) Activity-guided isolation and identification of free radical-scavenging components from various leaf extracts of Sorbus aria (L.) Crantz. Nat Prod Res, 26, 243-254 